\title{
Strategy for Managing Public Park Maintenance as One Effort for the Implementation of Sustainable Green Open Space
}

\author{
Silia Yuslim \\ siliayuslim@trisakti.co.id \\ Department of Landscape Architecture \\ Faculty of Landscape Architecture and Environmental Technology \\ Universitas Trisakti, Kampus A Ged. K lt.6, Jl. Kyai Tapa No.1, Jakarta 11520
}

\begin{abstract}
The quality of green open space in DKI Jakarta is far from perfect. The management of maintaining Green Open Space which is still dominated by the government, especially in public parks, causes more than 50\% of parks to be poorly maintained. Research Objectives are to provide management strategies to maintain public parks that involve the community (non-government) so that the park can benefit the community and the environment. Several studies in Europe revealed that community involvement can increase park maintenance activities, so the quality of the park can be improved. Research methods are using observation and descriptive qualitative analysis. Data is collected through a two-way assessment matrix of the Leopold Method to the parties that will be involved (purposive sampling). Matrix formulation is done through Delphi analysis, from the results of in-depth discussions related to the results of previous research studies with the government involved in maintenance activities. The results showed that maintenance activities require the rule of law, synergy, transparency, the possibility for community participation, and Human Resources. With this strategy, it is hoped that public parks can function sustainably for the community and the environment.
\end{abstract}

Keyword: Maintenance management strategy; Public parks; Sustainable Green Open Space

\section{Introduction}

The issuance of Law No. 26/2007 concerning Spatial Planning, particularly Article 29, explains that Green Open Space of a city area is required to have a minimum proportion of $30 \%$ of its area, consisting of $20 \%$ Public Green Open Space and private RTH by $10 \%$. DKI Jakarta's Green Open Space in 2011 based on actual conditions was only $59.25 \mathrm{~km} 2(8.9 \%)$ of its area. DKI Jakarta's Green Open Space requirement based on the provisions of the Act, which is $30 \%$ of the total area, is $198.70 \mathrm{~km} 2$. So the shortage is still $134.45 \mathrm{~km} 2(21.1 \%)$, both in the form of public and private green open space ${ }^{1}$. This fact has led to the idea of optimizing the quality of Green Open Spaces, especially those that function as public spaces, which are already available. This quality improvement is very closely related to maintenance activities that must be carried out continuously.

\footnotetext{
${ }^{1}$ Novianty, Rizka, Henita Rahmayanti dan Amos Neolaka: Evaluasi Mengenai Kuantitas dan Kualitas Ruang Terbuka Hijau di Wilayah Dki Jakarta. Vol. 1, pp. 100 - 125. Jurnal Menara (2012)
} 
According to Law No. 26 of 2007 concerning Spatial Planning ${ }^{2}$, to be exact Article 28, explained that the form of green open space in a city developed as a public space (public park), includes an Environmental Park which is a RT Park, RW Park, Village Park, District Park, City Park, RTH Cemetery, Small Green Housing Neighborhood, Green Open on a narrow Environmental Road, Green Open on the river border, and Urban Forest. This research is focused on public parks that are more active in nature, so that the utilization of public involvement can be optimized.

At present, many public parks in DKI Jakarta are poorly maintained or receive less attention from visitors. Communities around the park are sometimes less interested in utilizing public parks. The first case, Taman Simanjuntak Timur which is located in Cipinang Cempedak Village, East Jakarta, is a poorly maintained public park. This park, which has quite a lot of visitors, looks pretty sad. Based on observations, it can be seen that there is a gap between the needs of the surrounding community and facilities in the park. The surrounding community also seems to be less concerned about the cleanliness and the existence of the park.

The second case, Taman Mataram Merah (Red Mataram Park) and Taman Mataram Putih (White Mataram Park) located in Selong District, Kebayoran Baru - South Jakarta. Red Mataram Park is very well maintained and well designed, but it is quiet of visitors. Park maintenance is carried out intensively by CSR Prudential for 2 years (2018 and 2019). This is because the park was designed and built as a Financial Literacy Park at the expense of Prudential CSR. If the maintenance contract expires, it will not be known what will happen to the park in the future. While the White Mataram Park, which is located across the Red Mataram Park, is poorly maintained and also empty of visitors. The maintenance of White Mataram Park is carried out by the South Jakarta Forest Service, which in this case is the governmen.

The third case, Taman Utama Raya, located in Cengkareng Barat Village, West Jakarta. The condition of the park is not maintained and is empty of visitors. Based on observations, there is a gap between the needs of the local community and park facilities. Local people do not appreciate the existence of the park. This can be seen from the amount of vandalism found there. Meanwhile, Child-Friendly Integrated Public Space,

Pendongkelan Park, Cengkareng, West Jakarta is a public park that is managed jointly by the community and the local government. At the beginning of planning, local communities were involved to obtain input on their hopes for the park to be built. This is intended so that community expectations can be realized in the design of the park

And the fourth case, the Monas public park, located in Central Jakarta, is adjacent to the government area. This park is quite well-maintained. On certain days or holidays, the park is quite crowded with visitors from various regions.

Based on the case study, it can be seen that the park is poorly maintained, causing its role to improve the quality of the city environment and the container of activities for city communities to be less than optimal. One reason is the maintenance of public parks that are still dominated by the government. Limited funds and human resources for maintenance activities, is the cause. As a result, maintenance activities are only focused on public parks in the city center.

The provisions regarding efforts to involve the public in the provision and use of parks related to maintenance activities are in the Minister of Public Works Regulation No. 5 / PRT /

${ }^{2}$ Undang-undang Republik Indonesia No. 26 Tahun 2007 tentang Penataan Ruang 
M / $2008^{3}$ concerning Provision and Utilization of Urban Green Open Space in Urban Area. However, in its implementation, these efforts have not been able to be carried out optimally. Management of public park maintenance should be a joint responsibility between the government and the public (outside the government. For this reason, efforts are needed to activate the involvement of various parties outside the government, especially the local community. For this involvement to run optimally, maintenance management strategies that can facilitate the parties involved, so that maintenance activities can run effectively and efficiently. In the end, with a relatively limited area, public parks can still support the sustainability of green open space.

Research in several countries reveals the maintenance of public parks that implement public involvement. For example, the Danish City involved the community in maintaining various natural areas through the 'Give Nature a Hand' project ${ }^{4}$; maintenance of urban green spaces in Spain implements public involvement through cooperation with social organizations and voluntary associations which ultimately reduce the costs of financial maintenance activities $^{5}$. This strategy at a relatively low level can be implemented in schools with roots in the Spanish tradition ${ }^{6}$. The results of the study indicate public sector budget funding for urban green space management ${ }^{7}$. In the work of managing public facilities, the stages of planning, designing, implementing, and maintaining public facilities can be done by involving all parties, to work together transparently and synergistically ${ }^{8}$. Although maintaining green space with public involvement still has weaknesses, many good things can be applied according to the needs of this research.

\section{Method}

This research uses descriptive qualitative observational analysis methods. Sampling is done by purposive sampling, by distributing a two-way assessment matrix of the Leopold Method to the parties involved. The preparation of the matrix begins with the Delphi analysis, which begins with the results of previous research studies discussed with those involved in maintenance activities.

The two-way assessment matrix of the Leopold method is created to obtain an assessment of the relationship between the functions played by public parks according to their location and the components that must be considered in developing public involvement in maintenance management. The research location used as an observation case was carried out by taking

\footnotetext{
${ }^{3}$ Peraturan Menteri Pekerjaan Umum No. 5/PRT/M/2008 tentang Penyediaan dan Pemanfaatan Ruang Terbuka Hijau Kawasan Perkotaan

${ }^{4}$ Danmarks Naturfredningsforening: Giv naturen en hånd, http://www.dn.dk/Default. aspx?ID=20621 (2013)

5 Ankestyrelsen: Det kommunale samarbejde med frivillige sociale foreninger. §18-redegørelsen Socialministeriet, København (in Danish) (2010)

6 Arts, B., Leroy, P. and Van Tatenhove, J.: Political modernization and policy arrangements: a framework for understanding environmental policy change. Rev. 6, pp. 93-106. Public Organ (2006)

${ }^{7}$ Randrup, T.B., Persson, B.: Public green spaces in the Nordic countries: development of a new strategic management regime. 8, 882 31-40. Urban Forest, Urban Green (2009)

${ }^{8}$ Nasir, Mohamed Ikhwan, Mohamed Anuar, and Masran Saruwono: Barriers of User's Involvement in the Design Process of Public Parks as Perceived by Landscape Architects, Vol. 3, pp. 253-259. Journal Procedia - Social and Behavioral Sciences, Published by Elsevier 1877-0428 (2012)
} 
samples of one or two public parks located in the four administrative city areas located in DKI Jakarta. The study was conducted in 2018.

From the results of observations, there are three groups of public parks related to the function played by public parks according to their location. The first group, public parks in a residential environment with a lower-middle economic level. The second group, public parks in residential neighborhoods with middle to upper economic levels. The third group, public parks in the office building or public facilities. Five components must be considered in efforts to implement public involvement in the management of maintaining public parks, namely the rule of law, participation, synergy, transparency, and human resources. The matrix is filled in by parties who will be involved in the management and maintenance of public parks, including the DKI Jakarta Provincial Office, several environmental observers, community leaders, and some professional Landscape Architects.

\section{Result and Discussions}

Based on comparative studies from previous research in several European countries, it appears that public involvement is an alternative that can also be applied in Jakarta. For this reason, this research focuses on efforts to maintain public parks that provide opportunities for the community to be involved. Regarding the application of public involvement that is applied to maintenance management in Europe, the management strategy of maintaining public parks with public involvement that will be pursued in Jakarta requires improvement.

Table 1 Two-Way Matrix of Linkages between Types of Maintenance Activities with the Required Device

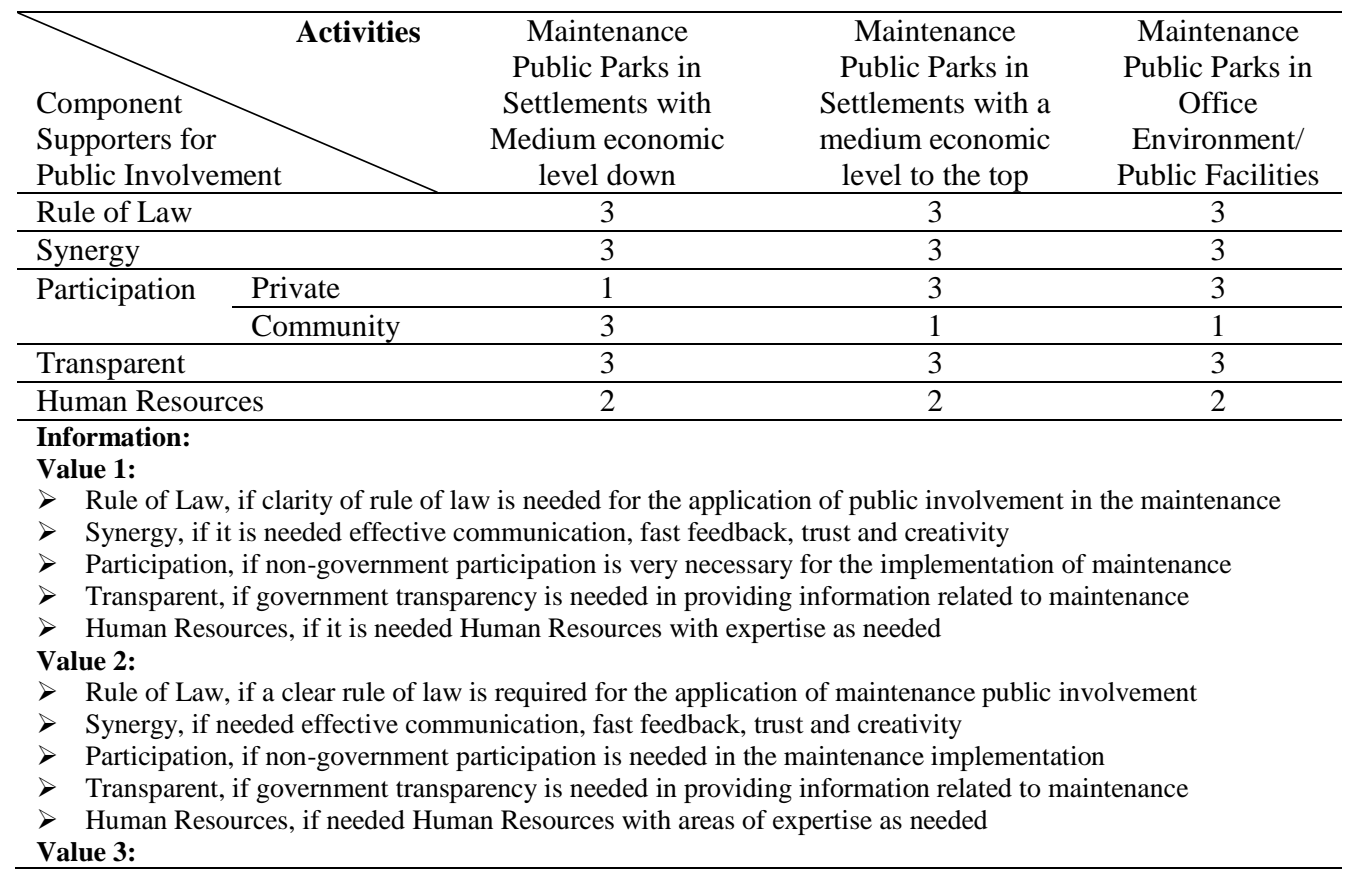


$>$ Rule of Law, if lack of clarity of the rule of law for the application of public involvement in the maintenance

$>$ Synergy, if less effective communication is needed, fast feedback, trust, and creativity

$>$ Participation, if non-government participation is lacking in maintenance implementation

$>$ Transparent, if government transparency is not needed in providing information related to maintenance

Human Resources, if very less needed Human Resources with expertise as needed

\subsection{Rule of Law}

Taman Mataram Merah (Red Mataram Park) is a public park located in Selong Village, Kebayoran Baru District, South Jakarta, where planning, design, implementation, and maintenance management utilize public involvement, in this case, the private sector. Based on the results of in-depth interviews with various parties involved ranging from planning, design, implementation, and management of the maintenance of the Red Mataram Park obtained information that can be used as input. This park was built at the expense of Prudential's Corporate Social Responsibility (CSR).

During the design process, the consultant made the design based on input from the funders, so that the design of the Red Mataram Park became a thematic park with the theme 'Financial Literacy Park'. The existence of this park is expected to provide education related to insurance. The location of the Red Mataram Park which is in a residential environment with middle to the upper economic level, the theme of Financial Literacy is not suitable. This is because basically a theme park with the theme of Financial Literacy will be more useful if applied to parks located in settlements with a lower-middle economic level. However, in the end, the park construction process can be carried out.

The park development process must go through several stages of bureaucracy to have a license for the implementation of less comfortable designs. Likewise, at the handover of the Mataram Park after the design was completed. This causes CSR Prudential, which is a funder, to feel deterrent from applying it to other public parks. Besides, when maintenance actions will be implemented, the same thing also happens. The accumulation of all these events caused the funding party, namely CSR Prudential and the maintenance sub-contractor, to no longer want to extend their maintenance contract.

Concerning public involvement as a management strategy for maintaining public parks, it is necessary to improve existing governance. This governance involves representatives from all parties involved in maintenance management. Also, the new government must have clear the role of law, division of authority and responsibilities, which in turn will regulate the division of labor and clear work procedures. This is because to realize a public park, it requires the involvement of various parties, including the government, consultants, project implementation contractors, maintenance contractors, and supervisors. The rule of law is a just legal framework, carried out indiscriminately, especially laws relating to human rights ${ }^{9}$. With this, the existence of a clear organizational structure, as well as the clarity of the dimensions of the rules focusing on interaction/coordination between various parties involved, related to formal procedures and informal routines will cause the distribution of tasks to be clearer and decision making to be faster. Thus, budget efficiency can be achieved.

9 Sedarmayanti: Good Governance (Kepemerintahan yang Baik) dalam Otonomi Daerah Upaya Membangun Organisasi Efektif dan Efisien melalui Restrukturisasi dan Pemberdayaan. Bandar Maju, Bandung (2003) 


\subsection{Synergy}

In one case, the Child-Friendly Green Public Open Spaces is one of the public parks that was built taking into account the expectations of the local community. Observation results show that the affection and ownership of the local community towards the park is quite good. The park is still well maintained. Through community and government involvement from the beginning, the community will also be motivated to maintain it. This can facilitate the process of technical outreach related to public park maintenance activities. With a smooth and communicative socialization process, maintenance management will also run well. Basically, in an activity involving several parties, good coordination is needed ${ }^{10}$. This is intended so that communication can run effectively and feedback can be conveyed quickly.

The above description shows that synergy is needed to produce optimal public involvement. To make this happen, it can be done through the implementation of Focus Group Discussion (FGD) to the parties involved (private and community) to socialize everything needed related to maintenance.

\subsection{Participation}

The participation component is divided into participation from the private sector and the community, or both. This component is intended to increase community ownership of public parks where they will be involved in maintenance activities. To optimally stimulate public involvement is to involve the local community from the beginning of the planning of the park. This is because basically they already have a simple knowledge of the process of making the park as a whole, such as planning, design, and management. This knowledge can be increased through the implementation of Focus Group Discussions (FGD). This fact is consistent with ${ }^{11}$ research on the use of local resources in urban park planning in Belgium, where basically local community members also think of an overall process that is no different from conventional stages such as planning, design, and management. This process has a picture that is almost the same as the stage in the project cycle ${ }^{12}$, namely the conceptual stage (the stage for compiling and formulating ideas); the planning and consolidation stage (the continuation stage of the conceptual stage, which prepares the design and discusses the parties to be involved); and implementation phase (implementation phase); and the operation phase (routine operations and maintenance). With full involvement, the sense of belonging to the park that has been planned and designed becomes even greater. This can reduce the desire to damage the park or vandalism.

The extent of involvement in the conventional stages of making (planning, designing, and implementing) and managing public parks cannot be equated in each public park maintenance group. In public park maintenance groups in the middle to lower level settlements, community involvement starting from the planning, design, and management/maintenance stages can be more optimal. For public park maintenance groups in upper-middle-class settlements,

\footnotetext{
${ }^{10}$ Najiyati, Sri dan S.R. Topo Susilo: Sinergitas Instansi Pemerintah Dalam Pembangunan Kota Terpadu Mandiri (The Synergy of Goverment Institutions in The Transmigration Urban Development). Vol. 28 (2), pp.113-124. Jurnal Ketransmigrasian (2011)

${ }^{11}$ Van Herzele, A., Collins, and K., Tyrväinen, L.: Involving people in urban forestry a discussion of participatory practices throughout Europe. Urban Forest and Trees. Springer, Berlin, pp. 207-228. (2005)

${ }^{12}$ Soeharto, Iman: Manajemen Proyek: dari Konseptual sampai Operasional. Erlangga, Jakarta (1995)
} 
community involvement is more common at the beginning (planning), but at the design and management/maintenance stages, private involvement can be further increased. For maintaining public parks in an office / public facility environment, community/manager involvement in the environment can be carried out starting from the planning, design and management/maintenance stages.

\subsection{Transparent}

Public involvement requires government openness in providing information related to maintenance. In the socialization of maintenance activities that will be carried out, it requires government transparency. Various information about regulations related to maintenance management, quality of maintenance actions, and maintenance activities, as well as the technical implementation of maintenance activities, must be accessible to the community or community organizations or private parties involved, especially those involved technically in the field. In addition, in the distribution of authority and responsibility for maintenance activities to the private sector and the community involved, there must also be openness. The socialization is related to all applicable rules, the implementation process, the technical implementation, and the quality of maintenance which is expected to be very good to be informed to all parties involved,

In the FGD process also must always maintain openness, so that discussions can be carried out so that consultants can find out exactly the community's needs for facilities in the park. The extent and limited funds, causing consultants to be able to filter, select, and place priorities in determining the facilities that best suit the needs of the local community

\subsection{Human Resources}

Regarding public involvement, research ${ }^{13}$ states that the perspectives, experiences and views of managers responsible for maintenance activities are an important focus. This is because in many cases citizens can start activities, but it is the manager who can make decisions if and how citizens can be involved. Therefore, key positions in government or authorities who are handed over responsibility for maintenance activities in an area require an educational background in the area of expertise, to guide their professional knowledge for the implementation of these activities. Therefore, maintenance managers and maintenance supervisors in the field are placed by people who are experts and skilled in their fields. This is because this position is the liaison and director for parties outside the government / public (public and private) in the implementation of maintenance activities.

In addition, in the field implementation, the supervisor directs and assists residents involved in maintenance activities, not only based on the results of personal experience from time to time but also based on their professional abilities. Thus, maintenance activities that can be dangerous can be avoided. This fact is consistent with the facts found in Jones's ${ }^{14}$ research,

\footnotetext{
${ }^{13}$ Molin, Julie Frøik and Cecil C. Konijnendijk van den Bosch: Between Big Ideas and Daily Realities The roles and perspectives of Danish municipal green space managers on public involvement in green space maintenance. Urban Forestry \& Urban Greening. Article Number 25426. Published by Elsevier $\mathrm{GmbH}(2014)$

${ }^{14}$ Jones, Robert: Theme: Local Government: With a Little Help From My Friends. Vol. 22, Issue 2. Journal Public Money \& Management (2010)
} 
namely that park officials base their work relationships with residents on their skills and experience that results from time to time, so training is needed.

\section{Conclusion}

Based on the discussion, it can be concluded that the strategy for maintaining public parks is to utilize public involvement. This is following government directives contained in the Ministerial Regulation on Guidelines for Provision and Utilization of Green Open Space in Urban Area. However, efforts are needed to realize the components needed to make it happen in the field, including the provision of law, synergy, participation, transparency, and human resources, which always pay attention to Safety, Occupational Health and the Environment (K3LH). Through the implementation of this strategy, it is expected that efforts to achieve the sustainability of the role and existence of green open space, especially public parks, can be achieved. Public involvement in managing public park maintenance must be carried out throughout the project cycle (from the beginning of planning, design, implementation and maintenance).

\section{References}

[1] Novianty, Rizka, Henita Rahmayanti dan Amos Neolaka: Evaluasi Mengenai Kuantitas dan Kualitas Ruang Terbuka Hijau di Wilayah Dki Jakarta. Vol. 1, pp. 100 - 125. Jurnal Menara (2012)

[2] Undang-undang Republik Indonesia No. 26 Tahun 2007 tentang Penataan Ruang

[3] Peraturan Menteri Pekerjaan Umum No. 5/PRT/M/2008 tentang Penyediaan dan Pemanfaatan Ruang Terbuka Hijau Kawasan Perkotaan

[4] Danmarks Naturfredningsforening: Giv naturen en hånd, http://www.dn.dk/Default. aspx?ID=20621 (2013)

[5] Ankestyrelsen: Det kommunale samarbejde med frivillige sociale foreninger. §18redegørelsen Socialministeriet, København (in Danish) (2010)

[6] Arts, B., Leroy, P. and Van Tatenhove, J.: Political modernization and policy arrangements: a framework for understanding environmental policy change. Rev. 6, pp. 93106. Public Organ (2006)

[7] Randrup, T.B., Persson, B.: Public green spaces in the Nordic countries: development of a new strategic management regime. 8, 882 31-40. Urban Forest, Urban Green (2009)

[8] Nasir, Mohamed Ikhwan, Mohamed Anuar, and Masran Saruwono: Barriers of User's Involvement in the Design Process of Public Parks as Perceived by Landscape Architects, Vol. 3, pp. 253-259. Journal Procedia - Social and Behavioral Sciences, Published by Elsevier 1877-0428 (2012)

[9] Sedarmayanti: Good Governance (Kepemerintahan yang Baik) dalam Otonomi Daerah Upaya Membangun Organisasi Efektif dan Efisien melalui Restrukturisasi dan Pemberdayaan. Bandar Maju, Bandung (2003) 
[10] Najiyati, Sri dan S.R. Topo Susilo: Sinergitas Instansi Pemerintah Dalam Pembangunan Kota Terpadu Mandiri (The Synergy of Goverment Institutions in The Transmigration Urban Development). Vol. 28 (2), pp.113-124. Jurnal Ketransmigrasian (2011)

[11] Van Herzele, A., Collins, and K., Tyrväinen, L: Involving people in urban forestry a discussion of participatory practices throughout Europe. Urban Forest and Trees. Springer, Berlin, pp. 207-228. (2005)

[12] Soeharto, Iman: Manajemen Proyek: dari Konseptual sampai Operasional. Erlangga, Jakarta (1995)

[13] Molin, Julie Frøik and Cecil C. Konijnendijk van den Bosch: Between Big Ideas and Daily Realities - The roles and perspectives of Danish municipal green space managers on public involvement in green space maintenance. Urban Forestry \& Urban Greening. Article Number 25426. Published by Elsevier GmbH (2014)

[14] Jones, Robert: Theme: Local Government: With a Little Help From My Friends. Vol. 22, Issue 2. Journal Public Money \& Management (2010) 